\title{
Choroidal metastases as a presenting manifestation of neuroblastoma
}

\author{
Renu P Rajan, Sagnik Sen 두, Naresh Babu Kannan 두, Kim Ramasamy
}

Department of Retina-Vitreous services, Aravind Eye Hospital, Madurai, India

Correspondence to Dr Sagnik Sen; riksag@gmail.com

Accepted 19 June 2020
D Check for updates

(c) BMJ Publishing Group Limited 2020. No commercial re-use. See rights and permissions. Published by BMJ.

To cite: Rajan RP, Sen $S$, Kannan NB, et al. BMJ Case Rep 2020;13:e235730. doi:10.1136/bcr-2020235730

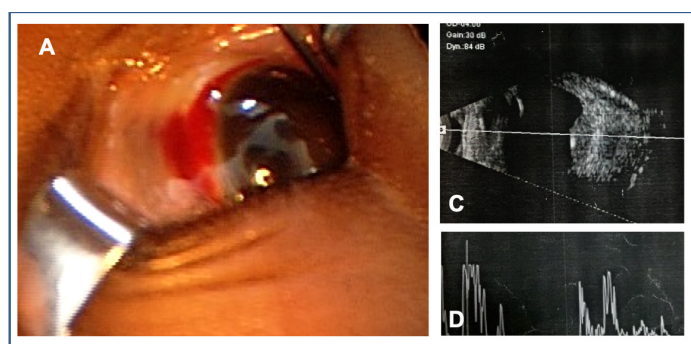

B

B of child showing subconjunctival haemorrhage. (B) Subretinal yellowish mass in nasal retina. $(C, D)$. Ultrasound (B) and (A) scan showing subretinal mass choroidal in origin.

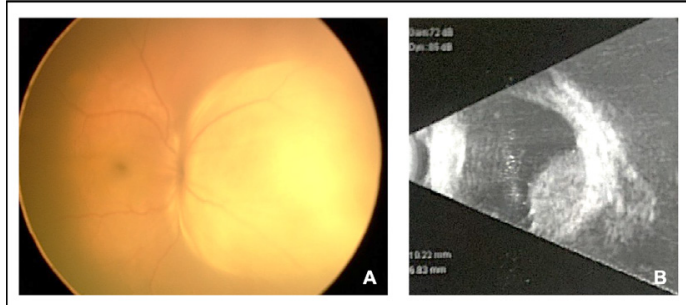

Figure 3 Enlarged choroidal mass at 2 weeks $(A)$ with corresponding ultrasound image (B).

\section{DESCRIPTION}

Neuroblastoma is a rare childhood malignancy sometimes presenting with orbital metastasis and proptosis. Here, we present a very rare case of intraocular metastasis of neuroblastoma, with an ophthalmologist being the first physician to diagnose the underlying serious systemic ailment.

A 3-month-old healthy child, born of a term pregnancy, presented to our centre with mother reporting right eye redness for 2 days. Both eyes were apparently normal in size and there were no obvious facial dysmorphisms or pigmentation.

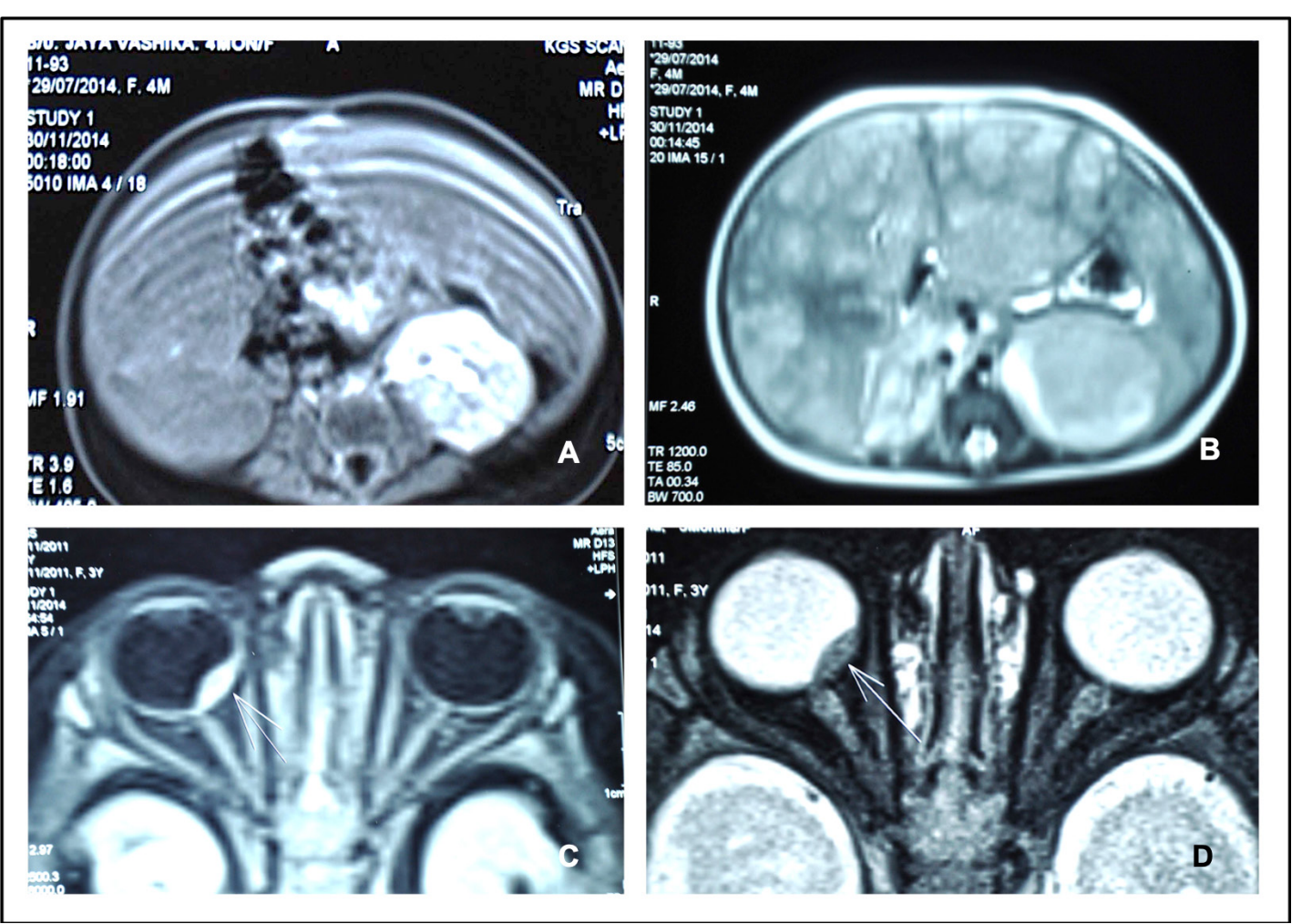

Figure 2 MRI scans of adrenal gland (A), liver (B) and right eye (C, D) showing T1 hyperintense mass originating from left adrenal gland and metastasising to liver and right eye posterior segment. 
Anterior segment examination of the right eye revealed subconjunctival haemorrhage (figure 1) located on the nasal side, while the left eye was within normal limits. The child was fixing with both eyes. There was no proptosis or visible posterior extension of the subconjunctival haemorrhage. Both eyes showed orange glow. Dilated fundus evaluation revealed an elevated choroidal mass lesion adjacent to the optic disc in the right eye (figure 1), while the left eye was normal. Ultrasonography of right eye showed a choroidal mass lesion with no calcification (figure 1). Whole-body MRI and MRI orbits revealed neuroblastoma of left adrenal gland with extensive metastasis to the liver and right eye choroid (figure 2). When the child returned with MRI reports, the eye mass had significantly enlarged rapidly (figure 3 ). The child was diagnosed with Stage 4 high-risk neuroblastoma and was referred for further management to a higher centre.

Neuroblastoma, an undifferentiated malignant tumour of the primitive neuroblasts, is the most common cancer during infancy. ${ }^{1}$ The origin of the tumour is primarily from the sympathetic nervous system in the abdomen in $60 \%$ cases, and most cases are reported before 4 years of age. ${ }^{2}$ At first diagnosis, more than $50 \%$ of patients present with distant organ metastases, including lymph node, bones, liver, intracranial and lungs. ${ }^{3}$

Learning points

- Choroidal lesions indicate metastatic disease even in the paediatric population.

- Metastatic neuroblastoma may rarely present as choroidal lesions, and, as such, merit thorough consideration and evaluation.

- Choroidal metastases may progress extremely rapidly and choroidal metastases in a case of neuroblastoma may indicate end stage of disease.
Metastases are mostly believed to occur via haematogenous route. Eye manifestations in neuroblastoma can be in the form of exophthalmos, periorbital ecchymoses, lid swelling, chemosis, disc oedema, strabismus, with the most common location for eye metastases being the choroid. ${ }^{4}$ However, choroidal metastases as a presenting manifestation of neuroblastoma are quite rare. This kind of presentation needs urgent imaging to look for the primary origin and treatment has to be titrated according to the staging of the disease. Treatment of advanced stage high-risk neuroblastoma includes chemotherapy, radiation therapy, bone marrow/haematopoietic stem cell transplantation, radioactive iodine therapy, biological-based therapy and immunotherapy with granulocyte-macrophage colony-stimulating factor and interleukin 2.5

Contributors RPR: idea, writing, proofing. SS: writing. NBK and KR: proofing.

Funding The authors have not declared a specific grant for this research from any funding agency in the public, commercial or not-for-profit sectors.

Competing interests None declared.

Patient consent for publication Parental/guardian consent obtained.

Provenance and peer review Not commissioned; externally peer reviewed.

\section{ORCID iDs}

Sagnik Sen http://orcid.org/0000-0001-5835-5371

Naresh Babu Kannan http://orcid.org/0000-0002-3993-9790

\section{REFERENCES}

1 Zhang N, Lin LK. Presumed primary orbital neuroblastoma in a 20-month-old female. Ophthalmic Plast Reconstr Surg 2010;26:383-5.

2 Sofi RA, Khanday SB, Keng MQ, et al. A case of primary orbital neuroblastoma. Int J Case Rep Imag 2012;3:16-18.

3 David R, Lamki N, Fan S, et al. The many faces of neuroblastoma. Radiographics 1989:9:859-82.

4 Lanzkowsky P. Neuroblastoma. In: Lanzkowsky P, ed. Annual of pediatric hematology and oncology. 4th edn. London: Elsevier Academic Press, 2016: 200. 530-2.

5 Matthay KK, Villablanca JG, Seeger RC, et al. Treatment of high-risk neuroblastoma with intensive chemotherapy, radiotherapy, autologous bone marrow transplantation, and 13-cis-retinoic acid. children's cancer group. N Eng/ J Med 1999;341:1165-73.

Copyright 2020 BMJ Publishing Group. All rights reserved. For permission to reuse any of this content visit https://www.bmi.com/company/products-services/rights-and-licensing/permissions/

BMJ Case Report Fellows may re-use this article for personal use and teaching without any further permission.

Become a Fellow of BMJ Case Reports today and you can:

- Submit as many cases as you like

- Enjoy fast sympathetic peer review and rapid publication of accepted articles

- Access all the published articles

- Re-use any of the published material for personal use and teaching without further permission

Customer Service

If you have any further queries about your subscription, please contact our customer services team on +44 (0) 2071111105 or via email at support@bmj.com.

Visit casereports.bmj.com for more articles like this and to become a Fellow 